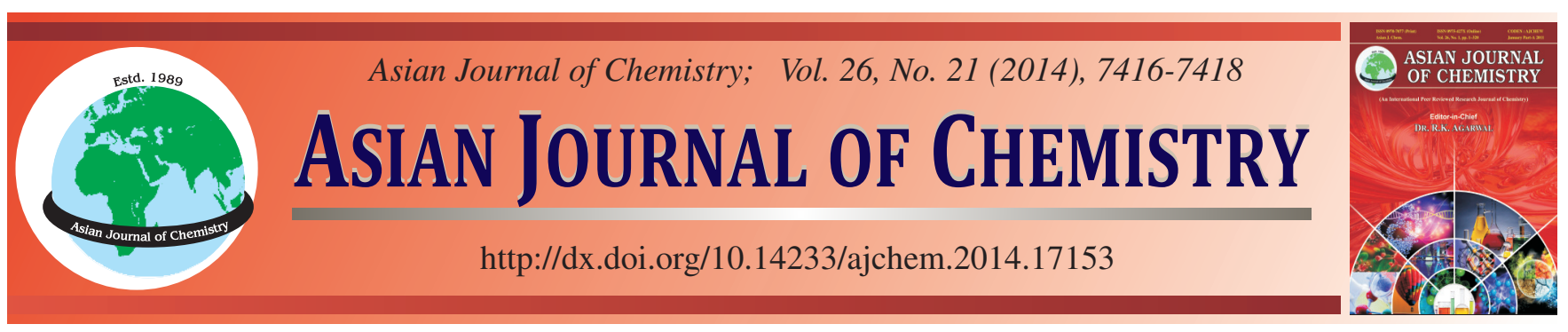

\title{
Preparation, Characterization and Physicochemical Behaviour of New Acetylated Schiff Base Ligand and its Metal Complexes
}

\author{
NARJis Naz ${ }^{1, *}$, Humayun AJAZ ${ }^{2}$ and Zubi SAdiQ ${ }^{1}$
}

${ }^{1}$ Department of Chemistry, Lahore College for Women University, Lahore-54000, Pakistan

${ }^{2}$ Department of Chemistry, University of Engineering and Technology, Lahore-54000, Pakistan

*Corresponding author: E-mail: narjis107@gmail.com

Received: 31 January 2014;

Accepted: 2 May 2014;

Published online: 30 September 2014;

AJC-16151

\begin{abstract}
We wish to report herein some new metal complexes of (S)-5-[(E)-3-(2-hydroxybenzylidene)guanidine]-2-acetamido pentanoic acid. Acetylation was successfully executed by the action of acetic anhydride on condensed product of salicylaldehyde and L-arginine named (S)-5-[(E)-3-(2-hydroxybenzylidene)guanidine]-2-amino pentanoic acid. Bidentate ligand was coordinated with $\mathrm{Ni}(\mathrm{II}), \mathrm{Fe}(\mathrm{II}), \mathrm{Cr}(\mathrm{III})$, $\mathrm{Mn}(\mathrm{II}), \mathrm{Zn}$ (II) and $\mathrm{Cu}$ (II) salts to furnish their respective metal complexes. FTIR, UV-visible. and MS spectrum of ligand and metal complexes were studied. TGA analysis showed thermal properties of compounds while their crystal systems were proved by X-ray diffraction technique. The results suggested that the ligand is bonded to metal through hydroxyl oxygen and the imino nitrogen.
\end{abstract}

Keywords: Schiff base, Metal complex, Amino acid, Ligand, Acetylation.

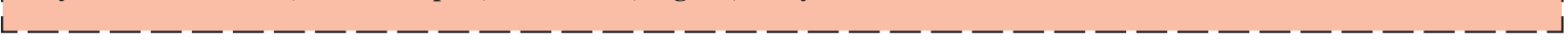

\section{INTRODUCTION}

Chiral molecular chemistry is well established in nature. This is the reason that left-handed (L) form of amino acids is frequently used in protein synthesis ${ }^{1}$. Modern aspects of organic preparations have turned to prepare industrially and pharmacologically crucial molecules by using asymmetric reagents. L-Arginine derived Schiff base ligand is a representative example in the context of above theme ${ }^{1}$. A Schiff base gets azomethine group $(\mathrm{C}=\mathrm{N})$ by condensation reaction between active carbonyl group of aldehyde/ketone and primary amine in acid or basic media. Considerable attention has been devoted in modifying its structure ${ }^{2}$.

Transition metal incorporation in ligand chemistry or chelation is fundamental process that enhances the potency of simple molecules and makes them more bio-active ${ }^{3,4}$. Its numerous applications in various fields of life have been extensively studied by many researchers. They can be interesting catalysts, therapeutic agents, insecticides, dyes, polymers or molecular architectures as reported in literature ${ }^{5,6}$. Moreover, Schiff base inhibitors also act as effectual corrosion inhibitors against steel, aluminium and copper ${ }^{7-10}$.

In present study, we are describing an efficient synthesis, characterization and physicochemical pattern of new acetylated Schiff base derivative of L-arginine with salicylaldehyde followed by metal complexation with transition metal salts like $\mathrm{NiSO}_{4} \cdot 6 \mathrm{H}_{2} \mathrm{O}, \mathrm{FeSO}_{4} \cdot 7 \mathrm{H}_{2} \mathrm{O}, \mathrm{Cr}\left(\mathrm{NO}_{3}\right)_{3} \cdot 9 \mathrm{H}_{2} \mathrm{O}, \mathrm{MnSO}_{4} \cdot 3 \mathrm{H}_{2} \mathrm{O}$, $\mathrm{ZnSO}_{4} \cdot 7 \mathrm{H}_{2} \mathrm{O}$ and $\mathrm{CuSO}_{4} \cdot 5 \mathrm{H}_{2} \mathrm{O}$.

\section{EXPERIMENTAL}

Commercially available AR grade reagents and solvents were purchased from Aldrich, Fluka and E. Merck. Reaction monitoring was carried out by TLC using Merck silica gel 60 F254 (0.2 mm) plates. TLC plates were examined under UV lamp to visualize the compounds. FTIR spectra were recorded on FTIR spectrophotometer (JASCO-4100) using KBr discs. UV-visible. spectra of acetylated Schiff base and their metals complexes were achieved in DMSO on Hitachi (U-2800) spectrophotometer using range $200-800 \mathrm{~nm}$. Mass spectra (MS) were recorded at an ionizing voltage of $70 \mathrm{eV}$ on a Finnigan/ MAT95 spectrometer. For molar conductance Wescan-212 conductometer was used. Carlo Erba $1106 \mathrm{CHN}$ analyzer was used to perform elemental analysis. Thermal investigation was executed on Netzsch simultaneous thermal analyzer. Concentration of metal was calculated on Hitachi polarized Zeeman (Z-8000) atomic absorption spectrophotometer after considering proper acid digestion.

Preparation of acetylated Schiff base ligand; (S)-5-[(E)3-(2-hydroxybenzylidene)guanidine]-2-acetamidopentanoic acid: To the solution of salicylaldehyde $\mathbf{1}(122 \mathrm{mg}, 1 \mathrm{mmol})$ in ethanol $(10 \mathrm{~mL})$ was added L-arginine $2(174 \mathrm{mg}, 1 \mathrm{mmol})$ and refluxed for $7 \mathrm{~h}$. Few drops of $10 \% \mathrm{H}_{2} \mathrm{SO}_{4}$ were added as reaction catalyst. The condensation product was allowed to cool and filtered with suction. The crude product was washed with ethanol and dried in desiccators to get (S)-5-[(E)-3-(2-hydroxybenzylidene)guanidine]-2-aminopentanoic acid 3 (194 mg, $70 \%$ ). 
In second step, acetylation was achieved by refluxing compound 3 (278 mg, $1 \mathrm{mmol}$ ) with acetic anhydride (112 mg, $1.1 \mathrm{mmol})$ in presence of anhyd. sodium acetate $(13.6 \mathrm{mg}$, $0.165 \mathrm{mmol})$. The temperature was maintained at $140{ }^{\circ} \mathrm{C}$ for $6 \mathrm{~h}$ to ensure complete acetylation. Light brown crude precipitates were collected by vacuum filtration and recrystallized from ethanol to afford acetylated Schiff base ligand 4 (256 mg, $80 \%$ ).

Formation of metal complexes (I-VI): The ethanolic solution of acetylated derivative of Schiff base (2 equivalents, $20 \mathrm{~mL}$ ) was vigorously stirred with ethanolic solution of metal salt (1 equivalent, $10 \mathrm{~mL}$ ) for $15 \mathrm{~min}$ at room temperature followed by reflux at $80^{\circ} \mathrm{C}$ for $5 \mathrm{~h}$ in $\mathrm{RB}$ flask. The coloured solid product (depends upon respective metal salt) was isolated by vacuum filtration and washed with ethanol/methanol and dried in vacuum over $\mathrm{CaCl}_{2}$.

\section{RESULTS AND DISCUSSION}

L-Arginine being naturally occurring amino acid with two different kinds of $\mathrm{NH}_{2}$ groups (a and e) is frequently used in the synthesis of metal ligand complexes ${ }^{1}$. By using same approach, we condensed equimolar ratio of salicylaldehyde with L-arginine in slightly acidic media. Dual functional sulphuric acid not only catalyzed this reaction but also acted as dehydrating agent. After $7 \mathrm{~h}$ reflux, corresponding Schiff base compound (S)-5-[(E)-3-(2-hydroxybenzylidene)guanidine]-2-amino pentanoic acid was achieved that further reacted with acetic anhydride to give (S)-5-[(E)-3-(2-hydroxybenzylidene)guanidine]-2-acetamido pentanoic acid (SchemeI). Bidentate ligand made tetra binded complexes by reacting metal ions with acetylated derivative of Schiff base ligand in 1:2 mole ratio (Fig. 2). In case of $\mathrm{Cr}$ (III) complex, additional binding was provided from free carboxyl group of ligand giving hexa membered complex structure. The ligand on reaction with $\mathrm{NiSO}_{4} \cdot 6 \mathrm{H}_{2} \mathrm{O}, \mathrm{FeSO}_{4} \cdot 7 \mathrm{H}_{2} \mathrm{O}, \mathrm{Cr}\left(\mathrm{NO}_{3}\right)_{3} \cdot 9 \mathrm{H}_{2} \mathrm{O}, \mathrm{MnSO}_{4} \cdot 3 \mathrm{H}_{2} \mathrm{O}$, $\mathrm{ZnSO}_{4} \cdot 7 \mathrm{H}_{2} \mathrm{O}$ and $\mathrm{CuSO}_{4} \cdot 5 \mathrm{H}_{2} \mathrm{O}$ salts, yielded corresponding metal complexes having general formula $\mathrm{ML}_{2}$.

Amino acids are present in Zwitter ion form at neutral $\mathrm{pH}$. Our experimental conditions in first step of synthesis were very mild that did not disturb its Zwitter ion while condensation occurred between uncharged amino group of arginine and aldehydic group of salicylaldehyde ${ }^{1}$. Acetylation was only done on $\mathrm{NH}_{2}$ group due to its greater reactivity as compared to $\mathrm{OH}$ group. Moreover this step was statistically controlled and product verification was done by spectral means.
This newly synthesized acetylated Schiff base ligand and its metal complexes are solid and highly stable at room temperature. The stability of complexes is due to presence of a second functional group (attached to amine and aldehyde unit) suitably placed at the site of condensation to form five or six membered chelating ring. Intramolecular hydrogen bonding (Fig. 1) is responsible for stabilization of compound which permit it to get a 3-D network structure. Solubility of all compounds is best in methanol while they are insoluble in $n$-pantane. Empirical formula, molecular weight, colour, melting point, yield, molar conductance and thermal gravimetric analysis of ligand and I-VI complexes are presented in Table-1. The molar conductance in DMSO solution of all prepared compounds were in range of 6.2-6.9 $\Omega^{-1} \mathrm{~cm}^{2} \mathrm{~mol}^{-1}$ which shows their non-electrolytic nature ${ }^{11,12}$. This analytical data is fairly acceptable and closed to proposed stoichiometry of the complexes. Elemental analysis of all prepared compounds is given in Table- 2 .<smiles>CN(Cc1ccccc1O)C(=N)NCCC[C@H](NC(=O)O)C(=O)O</smiles>

Fig. 1. Structural representation of hydrogen bonding<smiles>N=C(/N=C\NC(=N)NCCC[C@H](NC(=O)O)C(=O)O)NCCC[C@H](NC(=O)O)C(=O)O</smiles>

$\mathrm{M}=\mathrm{Ni}, \mathrm{Fe}, \mathrm{Cr}, \mathrm{Mn}, \mathrm{Zn}$ and $\mathrm{Cu}$

Fig. 2. Suggested structure for metal chelated ligand complex (5I-5VI)

Atomic absorption results revealed the theoretical value of metal in metal (II) complex that was with good agreement of experimental value in which ligand and metal ratio is $2: 1$.

Results of FTIR and absorbance spectra are Table- 2 to show the difference in peaks. Electronic spectra is recorded in range of $200-800 \mathrm{~nm}$. The characteristic bands at 280,382 and $345 \mathrm{~nm}$ for acetylated ligand is due to $\pi-\pi^{*}$ and $n-\pi^{*}$ transition of azomethine $(\mathrm{C}=\mathrm{N})$ group ${ }^{13,14}$. These absorption bands show the acetylated behaviour of ligand. Removal of<smiles>O=Cc1ccccc1O</smiles>
1<smiles>N=C(N)NCCC[C@H](N)C(=O)O</smiles>

2

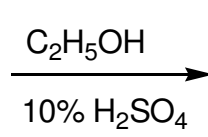<smiles>N=C(N=Cc1ccccc1O)NCCC[C@H](N)C(=O)O</smiles><smiles>CC(=O)OC(C)=O</smiles><smiles>N=C(N=Cc1ccccc1O)NCCC[C@H](NC(=O)O)C(=O)O</smiles>

Scheme-I: Synthesis of acetylated Schiff base ligand 


\begin{tabular}{|c|c|c|c|c|c|c|c|c|c|c|}
\hline \multicolumn{11}{|c|}{$\begin{array}{c}\text { TABLE-1 } \\
\text { PHYSICAL DATA AND TGA STATISTICS OF ACETYI }\end{array}$} \\
\hline Entry & $\begin{array}{l}\text { Compd. } \\
\text { No. }\end{array}$ & \multicolumn{2}{|c|}{$\begin{array}{l}\text { Empirical } \\
\text { formula }\end{array}$} & $\begin{array}{l}\text { Mol. wt } \\
(\mathrm{g} / \mathrm{mol})\end{array}$ & Colour & m.p. $\left({ }^{\circ} \mathrm{C}\right)$ & $\begin{array}{l}\text { Yield } \\
(\%)\end{array}$ & $\begin{array}{l}\text { Conductivity } \\
\left(\Omega^{-1} \mathrm{~cm}^{2} \mathrm{~mol}^{-1}\right)\end{array}$ & $\begin{array}{c}\text { Mass loss (\%) } \\
\text { calculated (found) }\end{array}$ & $\begin{array}{l}\text { Residue (\%) } \\
\text { calculated } \\
\text { (found) }\end{array}$ \\
\hline 1 & $\mathrm{~L}$ & \multicolumn{2}{|c|}{$\mathrm{C}_{15} \mathrm{H}_{20} \mathrm{~N}_{4} \mathrm{O}_{4}$} & 320 & Light brown & 210 & 80 & - & 13.8 & 86.2 \\
\hline 2 & I & \multicolumn{2}{|c|}{$\left(\mathrm{C}_{15} \mathrm{H}_{20} \mathrm{~N}_{4} \mathrm{O}_{4}\right)_{2} \mathrm{Ni}$} & 699 & Light green & 230 & 75 & 6.7 & $24.8(25.8)$ & $75.2(74.2)$ \\
\hline 3 & II & \multicolumn{2}{|c|}{$\left(\mathrm{C}_{15} \mathrm{H}_{20} \mathrm{~N}_{4} \mathrm{O}_{4}\right)_{2} \mathrm{Fe}$} & 696.5 & Yellow brown & 280 & 84 & 6.2 & $24.9(25.7)$ & $75.1(74.3)$ \\
\hline 4 & III & \multicolumn{2}{|c|}{$\left(\mathrm{C}_{15} \mathrm{H}_{20} \mathrm{~N}_{4} \mathrm{O}_{4}\right)_{2} \mathrm{Cr}$} & 692.5 & Dirty green & 308 & 73 & 6.5 & $25.0(29.3)$ & $75.0(70.7)$ \\
\hline 5 & IV & \multicolumn{2}{|c|}{$\left(\mathrm{C}_{15} \mathrm{H}_{20} \mathrm{~N}_{4} \mathrm{O}_{4}\right)_{2} \mathrm{Mn}$} & 695.5 & Greyish brown & 265 & 79 & 6.6 & $24.9(28.1)$ & 75.1 (71.9) \\
\hline 6 & $\mathrm{~V}$ & \multicolumn{2}{|c|}{$\left(\mathrm{C}_{15} \mathrm{H}_{20} \mathrm{~N}_{4} \mathrm{O}_{4}\right)_{2} \mathrm{Zn}$} & 706 & Bluish green & 280 & 84 & 6.8 & $24.5(27.8)$ & $75.5(72.2)$ \\
\hline 7 & VI & \multicolumn{2}{|c|}{$\left(\mathrm{C}_{15} \mathrm{H}_{20} \mathrm{~N}_{4} \mathrm{O}_{4}\right)_{2} \mathrm{Cu}$} & 704 & White & 258 & 89 & 6.9 & $24.6(11.0)$ & $75.4(89.0)$ \\
\hline \multicolumn{11}{|c|}{$\begin{array}{c}\text { TABLE-2 } \\
\text { FTIR, UV-VISIBLE AND ELEMENTAL DATA OF LIGAND AND ITS METAL COMPLEXES (I-VI) }\end{array}$} \\
\hline \multirow{2}{*}{\multicolumn{2}{|c|}{ Compd. no }} & \multicolumn{3}{|c|}{ FTIR spectrum $\left(\mathrm{cm}^{-1}\right)$} & \multicolumn{2}{|c|}{ UV-visible spectrum $(\mathrm{nm})$} & \multirow{2}{*}{$\mathrm{C}$} & \multirow{2}{*}{$\mathrm{H}$} & \multirow{2}{*}{$\mathrm{N}$} & \multirow{2}{*}{ M } \\
\hline & & $v_{C=0}$ & $\mathrm{v}_{\mathrm{C}=\mathrm{N}}$ & $v_{\mathrm{N}-\mathrm{H}}$ & $\mathbf{v}_{\max }$ & & & & & \\
\hline $\mathrm{L}$ & & 1640 & 1118 & 3426 & $280,382,345$ & & $56.22(56.12)$ & $6.29(6.35)$ & $17.50(17.59)$ & - \\
\hline I & & 1629 & 1161 & 3461 & 282,333 & & $51.54(51.24)$ & $5.78(5.89)$ & $16.04(16.34)$ & $8.39(8.42)$ \\
\hline II & & 1630 & 1101 & 3470 & 281,335 & & $51.73(51.77)$ & $5.78(5.68)$ & $16.10(16.15)$ & $8.03(8.13)$ \\
\hline III & & 1636 & 1128 & 3405 & 285,331 & & $52.03(52.23)$ & $5.82(5.76)$ & $16.19(16.34)$ & $7.52(7.53)$ \\
\hline IV & & 1630 & 1147 & 3450 & 283,332 & & $51.80(51.85)$ & $5.80(5.90)$ & $16.10(16.02)$ & $7.91(7.95)$ \\
\hline V & & 1622 & 1121 & 3420 & 280,334 & & $51.04(51.09)$ & $5.72(5.77)$ & $15.86(15.81)$ & $9.27(9.32)$ \\
\hline VI & & 1526 & 1136 & 3460 & 284,330 & & $51.17(51.27)$ & $5.73(5.75)$ & $15.91(15.80)$ & $9.02(9.05)$ \\
\hline
\end{tabular}

particular band at $280 \mathrm{~nm}$ (which is owing to the imine group of ligand) is the right proposal of absolute renovation of ligand into its respective metal complex ${ }^{3,15}$. FTIR spectrum provided us important information about functional group present in our targeted molecules. The clear bands at 1640 and $1563 \mathrm{~cm}^{-1}$ indicating the presence of acetyl carbonyl group. There was no band in region of $3550-3300 \mathrm{~cm}^{-1}$ that ensured the complete acetylation of free amino group. The absorption band of azomethine group $(-\mathrm{CH}=\mathrm{N}-)$ is usually observed ${ }^{16}$ at 1650 $1630 \mathrm{~cm}^{-1}$. These low value band verifies the coordination via azomethine nitrogen ${ }^{17,18}$.

In thermal gravimetric evaluation, the acetylated Schiff base derivative showed two ladders decomposition pattern. The former disintegration starts at $50{ }^{\circ} \mathrm{C}$ and ends at $180{ }^{\circ} \mathrm{C}$ with mass loss of $13.8 \%{ }^{19,20}$. Ligand was stable from 200$450{ }^{\circ} \mathrm{C}$. The second decomposition range was $452-700$ with $9 \%$ loss and a molecule of carbon dioxide. The mass spectrum of acetylated Schiff base revealed molecular ion peak $\mathrm{M}^{+}$at 320 which shows the original molecular weight of ligand $\mathrm{C}_{15} \mathrm{H}_{20} \mathrm{~N}_{4} \mathrm{O}_{4}$. Other peaks are well clear at 161, $159(100 \%)$, 147,120 . Crystal nature of solid compounds was proved from crystallographic data using XRD technique.

\section{Conclusion}

As part of our efforts, we have synthesised Ni(II), Fe(II), $\mathrm{Cr}(\mathrm{III}), \mathrm{Mn}(\mathrm{II}), \mathrm{Zn}(\mathrm{II})$ and $\mathrm{Cu}(\mathrm{II})$ complexes with new acetylated Schiff base ligand formed by the condensation of salicylaldehyde and L-arginine followed be acetylation. The ligand and its chelated compounds were fully characterized by spectral, thermal and X-ray studies to set up the proposed four-coordinated geometry of complexes except chromium complex.

\section{ACKNOWLEDGEMENTS}

This work was supported by Central Laboratory of Lahore College for Women University and Research Lab of PCSIR, Pakistan.

\section{REFERENCES}

1. G.B. Roy, Inorg. Chim. Acta, 362, 1709 (2009).

2. W.-L. Liu, Y. Zou, C.-L. Ni, Z.-P. Ni, Y.-Z. Li, Y.-G. Yao and Q.-J. Meng, Polyhedron, 23, 849 (2004).

3. N. Naz, Z. Sadiq and M.Z. Iqbal, Asian J. Chem., 25, 297 (2013).

4. M. Sonmez, A. Levent and M. Sekerci, Russ. J. Coord. Chem., 30, 655 (2004).

5. M.B. Halli, V.B. Patil and S.R. Bevinamarada, Turk. J. Chem., 35, 393 (2011).

6. S. Kumar, D.N. Dhar and P.N. Saxena, J. Sci. Ind. Res. (India), 68, 181 (2009).

7. A.M. Atta, N.O. Shaker, M.I. Abdou and M. Abdelfatah, Prog. Org. Coat., 56, 91 (2006).

8. M.N. Desai, M.B. Desai, C.B. Shah and S.M. Desai, Corros. Sci., 26, 827 (1986).

9. S. Bilgiç and N. Çaliskan, Appl. Electrochem., 31, 79 (2001).

10. S. Li, S. Chen, S. Lei, H. Ma, R. Yu and D. Liu, Corros. Sci., 41, 1273 (1999).

11. M. Sekerci and C. Alkan, Synth. React. Inorg. Met-Org. Chem., 29, 1685 (1999).

12. M. Sekerci and E. Tas, Heteroatom Chem., 11, 254 (2000).

13. B. Bosnich, J. Am. Chem. Soc., 90, 627 (1968).

14. R.S. Downing and F.L. Urbach, J. Am. Chem. Soc., 91, 5977 (1969).

15. M. Sonmez and M. Sekerci, Pol. J. Chem., 76, 907 (2002).

16. K. Nakamoto, Infrared and Raman Spectra of Inorganic and Coordination Compounds, John Wiley Interscience, New York, p. 59 (1997).

17. N. Raman, S. Ravichandran and A. Kulandaisamy, Asian J. Chem., 14, 1261 (2002).

18. R.K. Agarwal, D. Sharma, L. Singh and H. Agarwal, Bioinorg. Chem. Appl., Article ID 29234 (2006).

19. N. Raman and S. Ravichandran, Pol. J. Chem., 78, 2005 (2004).

20. N. Naz, S. Khatoon, H. Ajaz, Z. Sadiq and M.Z. Iqbal, Asian J. Chem, 25, 2239 (2013). 